\title{
Self-Esteem in Shaping Youth Personality from Islamic Psycho-Spiritual Perspective
}

\author{
Che Zarrina Sa'ari \\ University of Malaya, zarrina@um.edu.my \\ Nur Ulfah Harun \\ University of Malaya, ulfaharun@um.edu.my
}

\begin{abstract}
Early childhood experiences profoundly affect later functioning as an adult. These experiences also involve the development of self-concept that has close relation to the Arabic term muru'ah or self-esteem in Islamic literature. Many scholars have proposed theories and models of self, including those based on Islamic teachings. This article aims to explore the concept of self-esteem in shaping youth personality based on the Islamic psycho-spiritual study using the method of content analysis. The self-esteem is regarded as a risk factor influencing social functioning and problem behaviour in youth contributing to different kind of mental health problems. There is also a link between the self-esteem and social behaviour which relate to the whole problem of personality disorder. A high self-esteem was found to be the most important factor for adjustment and for protection against common problem behaviour among youth. Whilst, low self-esteem has a direct effect on problem behaviour. In Islamic psycho-spiritual discipline, the sources of self-esteem are based on revelations of God without neglecting the empirical aspect of it as practised by psychologists. Thus, in shaping youth personality, selfesteem in Islam placed an equilibrium line between physical, psychological, spiritual and religious development. At the same time, sources of self-esteem also take into consideration in the collection of self-perceptions from social, physical, emotional, family, behavioural, academic, and the environment interaction outcomes like parents, family, teachers, friends and community members which do not contradict the teachings of Islam. Thus, through the conception of self-esteem build in Islamic psycho-spiritual discipline that combines sources from revelation of God and empirical of human beings' efforts, the benefits can be seen not only in the temporal aspect of one's life but also in the eternal.
\end{abstract}

Keywords: Islamic psycho spiritual, Muslim youth, self-esteem, muru'ah, personality.

\section{Introduction}

Almost every day, Malaysian society are exposed with the issues of discipline problems, crimes and social crisis among youths, despite the fact nearly 50\% of population in Malaysia are young 
people who should be an asset for the future of the country. A troubled teen or adolescent is a term used for a youth that is having problems which are causing negative behaviours and if these problems continue to affect the teen, he/she will not develop into a happy successful adult. Malaysia, in facing globalization, has received rapid growth in socio-economic and advance technologies. World without any barriers allows cultures from other countries influence Malaysians especially the youths. ${ }^{1}$

One of the factors of social problems among them emerged due to bad cultures from other countries which do not subscribe to local cultural and religious values. ${ }^{2}$ Most young generations cannot identify and analyse what are the good and bad things. Due to this situation, many of them involve in modern technologies and spend a lot of time in surfing immoral webs, addicted to games and many others bad deeds that is contrary to the teachings of Islam and the culture of Malaysian society. ${ }^{3}$

Until now, the public perception of religion and science are the two things that unable to be consolidated. ${ }^{4}$ They consider both of these elements to have a separate discussion and division at all between one another. This situation illustrates that science is not directly related to religion and religion separate from science. ${ }^{5}$ The religion of broad intent is Allah's revelation that regulates man's relationship with God, fellow human beings, and the environment physically, socially and culturally. ${ }^{6}$ It also carries rules, general

1 Sharifah Basirah Syed Muhsin \& Che Zarrina Sa'ari, Kaedah Prikoterapi Islam Berasaskan Konsep Maqamat Abu Talib Al-Makki (Kuala Lumpur: Dewan Bahasa dan Pustaka, 2015), 151.

2 Azizi Yahaya \& Halimah Ma'alip, Estim Kendiri Remaja (Skudai, Johor: Universiti Teknologi Malaysia, 2010), 5.

3 Nor Azah Abdul Aziz \& Che Zarrina Saari, "Menangani Permasalahan Laman Web Pornografi: Antara Perisian Penapis, Penguatkuasaan UndangUndang dan Amalan Spiritual," Journal of Islamic and Arabic Education 3, no. 1 (2011), 29-46.

4 M.Amin Abdullah et al., Integrasi Sains-Islam: Mempertemukan Epistemologi Islam dan Sains (Yogyakarta: Pilar Religia, 2004), 3.

5 M. Amin Abdullah, "Etika Tauhidik Sebagai Dasar Kesatuan Epistemologi Keilmuan Umum dan Agama," dalam Integrasi Sains-Islam: Mempertemukan Epistemologi Islam dan Sains (Yogyakarta: Pilar Religia, 2004), 3.

6 M. Amin Abdullah, "Etika Tauhidik Sebagai Dasar Kesatuan Epistemologi Keilmuan Umum dan Agama,"10. 
values and basic principles called the Shari ah. The Holy Qur'an as well as the Traditions of the Prophet Muhammad PBUH are references to the whole aspects of human life and become the source of theology of knowledge as well as the grand theory of science. $^{7}$

Based on the concept of the grand theory, the fundamental source of Islamic psychology spiritual studies differs from the Western psychological resources that are more empirical. Islam is indeed the source of truth, ethics, law and wisdom. However, Islam does not recognize Allah's revelation as the only source of knowledge. From this point of view, there are two sources of knowledge that is based on Allah's revelations and of human knowledge. The source of Islamic psychology spiritual study itself is based on theo-antropo-centric where both sources is fundamental in the study of knowledge. ${ }^{8}$

Youth are asset for future excellence in the country. Their ability to develop superior personality as required by religious teachings is an advantage to society and the nation. The formation of noble character emphasizes three main aspect; strengthening faith, enhancing worship and practicing good and commendable attitudes. Early childhood experiences profoundly affect later functioning as an adult. These experiences are involved with the development of self-concept that has close relation to Arabic term muru'ah or self-esteem, which were supposed to be built from the start of their lives. Muru'ah that has been discussed in Islamic knowledge is seen as one of the most important concept that plays a role in building the personality of youth. ${ }^{9}$

7 M. Amin Abdullah, "Etika Tauhidik Sebagai Dasar Kesatuan Epistemologi Keilmuan Umum dan Agama,"11.

8 M. Amin Abdullah, "Etika Tauhidik Sebagai Dasar Kesatuan Epistemologi Keilmuan Umum dan Agama,"11.

9 Alī Ibn Muhammad Ibn Habīb al-Māwardī, Ādāb al-Dunyā wa al-Dīn (t.tp: Jāmi' al-Ḥuqūq Mahfūẓah, 2007), 320; Abī Ḥasan 'Alī bin Muhammad Ḥabīb al-Basrī, Ādāb al-Dunyā wa al-Dīn (t.tp: Societi Algerolibanaise, 2006), 426. 


\section{The Concept of Self-esteem}

Self-esteem in the Arabic word is al-muru'ah ${ }^{10}$ denotes the meaning of the ability to maintain behavior or noble character by abandoning various attitudes, speeches and behaviors that can lower the dignity of human beings who are the best creations of Allah. ${ }^{11}$ This word also means manners and ethics that symbolize pious manners that require care to the perfection of moral and beauty habits or also known as a trait of human perfection (insan kamil). ${ }^{12}$ The word is also used to describe the height of the personality and morality of a person who also indicates the perfection of one's character.

Self-esteem in Islamic psycho-spiritual, is built based on Islamic ethics from which moral and spiritual values are one of the fundamental frameworks of Islamic teachings after faith and worships. ${ }^{13}$ The execution of human deeds in this context should be guided by Islamic moral values based on the teaching of Qur'an and the Sunnah. ${ }^{14}$ This implies that moral values (good and bad) in Islam are set primarily by religion, not changing human rational or perception which continue to evolve through time.

The elements of this kind of self-esteem according Ibn Qayyim al-Jawziyyah can be explained into three states of human psyche; the inciting soul (nafs al-ammarah bi al-su') that leads to the nature of the devil, the self-accusing soul (nafs al-lawwamah) that pushes man to bow to lust and the third soul is the soul at peace (nafs al-mutma'innah) that encourages man to the nature of angels. The nature of self-esteem in Islam is owned by rejecting the first two states of souls and completing the third impetus that brings humanity to the praiseworthy nature. ${ }^{15}$ This situation shows

10 Kamus Besar Arab-Melayu Dewan (Kuala Lumpur: Dewan Bahasa dan Pustaka, 2006), 2184, entri "Muruah", 2184.

11 Muhammad Ibrāhīm 'Abd Allāh al-Tuwijīīī, Mawsū'at Fiqh al-Qulūb fì Daw' al-Qur'ān wa al-Sunnah (Baridah: Dār Asdad al-Mujtami', 2012), 585.

Al-Mu'jam al- 'Arabī al-Asāsī (Alecso: n.p,1989), 1126, entri “"مروءة".

Al-Māwardī, Ādāb al-Dunyā wa al-Dīn, 324.

14 Rohana Binti Zakaria, Zikmal Fuad \& Mohd Nur Adzam Rasdi, "Implikasi Tadabbur Al-Quran dalam Pembentukan Insan Yang Berkualiti di Sudut Akhlak," (Paper presented in International Conference on Postgraduate Research 2014 (ICPR 2014), Kuala Lumpur, 1-2 December 2014), 266.

15 Ibn Qayyim al-Jawziyyah, Madārij al-Sālikīn: Bayn Manāzil Iyyāka Na 'bud wa Iyyāka Nasta'ìn (Beirut: Dār al-Kutub al-'Ilmiyyah, t.t), 2296; 
that positive self-esteem in the view of Islamic psychology spiritual is when one has capability to do all good deeds and avoid all bad deeds ${ }^{16}$ which then leads to self-preservation to always be in the glory of morality and beauty of character. ${ }^{17}$

It can be concluded that high self-esteem in Islam is the ability to maintain behavior and noble character by abandoning various attitudes, speeches and behaviors that can degrade and bring down the nobility of human beings who are God created in the best creation. Whilst the low self-esteem is the inability of one's self to disengage with the prohibited things by religious teachings either through attitude, conversation and act that degrade their dignity as righteous persons. Allah says in the Qur'an:

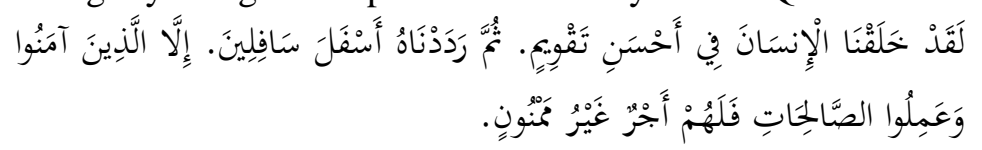

Al-Tin 95:4-6:

Certainly, We created man in the best make. Then We render him the lowest of the low. Except those who believe and do good, so they shall have a reward never to be cut off.

In Western psychology, self-esteem in this discipline is one of the widely used scales to measure an individual's overall selfassessment of whether a person has a high or low self-esteem. ${ }^{18}$ Coopersmith defines self-esteem as an individual assessment of worthiness that is expressed in attitudes the individual holds toward himself, thereby recognizing the extent to which an individual believes himself as capable, important, successful and worthy individual. In other words, self-esteem indicates the condition of a person to agree or disagree on his or her ability, capability, performance and value of interest. ${ }^{19}$ According to

Muhammad ibn Muhammad al-Ghazālī, Ihyā' 'Ulūm al-Dīn (Beirut: Dār alKutub al-'Ilmiyyah, 2001), 3:5.

16 Al-Tuwijīrī, Mawsū 'at Fiqh al-Qulūb fì Daw' al-Qur'ān wa al-Sunnah, 585.

17 Al-Tuwijīīi, Mawsū 'at Fiqh al-Qulūb fì Daw' al-Qur'ān wa al-Sunnah, 585.

18 Viktor Gecas, "The Self-Concept", Annual Review of Sociology, 8 (1982): 5; Azizi Yahya \& Halimah Ma'alip, Estim Kendiri Remaja, 5.

19 Stanley Coopersmith, The Antecedents of Self-esteem (San Francisco: W. H. Freeman and Company, 1967); Briam W. Johnson et al., "The Coopersmith Self-Esteem Inventory: A Construct Validation Study," Educational and Psychological Measurement, 43 (1983); Todd F. Heatherton, Carrie L. 
Gergen, self-esteem refers to a good sense of personal ability. ${ }^{20}$ It is a tribute to oneself by someone who has the desire to recognize oneself more deeply in terms of strength, capability and selfquality as well as action in which the action comes from within the result of a good feeling in one's life. ${ }^{21}$

The concept of self-esteem presented by Western philosophers and psychologists are based on empirical method ${ }^{22}$ built on the elements of humanism, rationalism, empiricism and various other philosophical thoughts. ${ }^{23}$ The approach used in assessing the self-esteem concept is also based on affective, cognitive and sociological approaches without any element of revelation or religious teaching as the primary source.

In comparison, the aim of self-esteem in Islamic and western studies is to produce good human beings. Both believe low selfesteem that leads to negative value in one's self can be corrected. ${ }^{24}$ High or low self-esteem can be formed through a good or bad feelings, speeches and actions. In western psychology, individual and social judgments are used as a basis for self-esteem. Selfesteem assessment takes into account the elements of self-concept, social views and personal perceptions. ${ }^{25}$ Individual self-esteem is assessed based on how the individual feels that he is part of a group of people (feeling of belonging), the feeling of the individual that he is capable of doing something to achieve (feeling of competence) and the individual's sense of worthiness (feeling of worthy). ${ }^{26}$ Human whom are considered as a

Wyland, \& S. J. Lopez, "Assessing self-esteem," Positive Psychological Assessment: A Handbook of Models and Measures (2003), 220.

20 Viktor Gecas, "The Self-Concept", 5; Wilis Srisayekti David A. Setiady \& Rasyid Bo Sanitioso. "Harga-diri (Self-esteem) Terancam dan Perilaku Menghindar”, Jurnal Psikologi 42 (2), (2015) 146.

21 Keith A. Dutton \& Jonathon D. Brown, "Global Self-Esteem and Specific Self-Views as Determinants of People's Reactions to Success and Failure" Journal of Personality and Social Psychology, 73 (1997): 139.

22 Azizi Yahaya, Estim Kendiri, 3.

23 Mohd Nasir Omar, Akhlak dan Kaunseling Islam (Kuala Lumpur, Utusan Publications and Distributors Sdn Bhd, 2005), 46.

24 Azizi Yahaya, Estim Kendiri, 7.

25 Azizi Yahaya, Estim Kendiri, 4.

26 D. Frey \& C. J. Carlock, Enhancing Self-Esteem (United States of America: Accelerated Development, Inc, 1987); Francis R. Kick, Jr. "The Self 
determinant of self-esteem, however cannot meet spiritual demands in forming high self-esteem since human assessment certainly has deficiencies and disabilities. Also contradictions across individual, communities, cultures, time etc.

Whereas the concept of self-esteem in Islam proposes a basis judgment based on revelation and religion in assessing the extent to which the individual is valued and regarded not only by the creature even by Allah the Almighty. Thus, the method of selfesteem assessment is based on the revelation of Allah as he says in

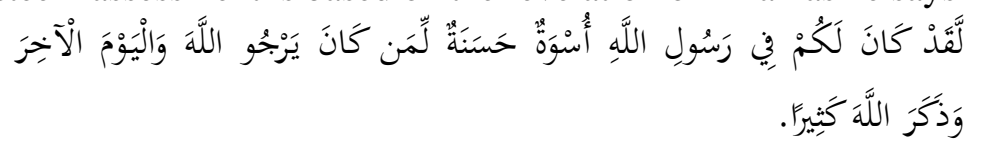

Al-Aḥzāb 33:21:

Certainly, you have in the Messenger of Allah an excellent exemplar for him who hopes in Allah and the latter day and remembers Allah much.

Assessment of self-esteem in this discipline is not only related to attitude and personality, but it also includes spiritual elements that have a direct relationship with the Creator. ${ }^{27}$ Islam also regulates Shari ah and intellectual evaluations in determining the good and bad deeds. All religious instructions are good characters which lead one's self to high self-esteem, whilst religious restrictions are bad manners which lead one's self to low self-esteem. ${ }^{28}$

From the above discussion, the focus on self-esteem development in Western psychology is seen to be more vertical (man to man) rather than horizontal (man to Creator) as may be found in Islam and serves only to meet self-will and community demands.

\section{Self-esteem in Shaping Youth Personality}

According to Roges, the term of teenage or adolescence or youth means to grow or grow into maturity. Based on that definition, teenage/adolescent/youth is a process and is not directly tied to the length of time. The process here indicates the process of achieving

Perceptions of Self-Concept and Self-Esteem: A Theoretical Analysis" (Master Thesis, Antioch University, 1992), 24.

27 Mohd Nasir Omar, Akhlak dan Kaunseling Islam, 12.

28 Mohd Nasir Omar, Akhlak dan Kaunseling Islam, 16. 
or attaining the necessary attitudes and beliefs for effective engagement in society. ${ }^{29}$ The adolescent phase is a transition period from childhood to adolescent age which starts with puberty up to the age of $30 .^{30}$

Adolescent is at the third stage of life tending to beautify (zinah) themselves starting around the age of 14 until the age of 24. They no longer think about themselves, but how they can have and being acknowledged by others. ${ }^{31}$ The question of who I am? How should I live my life? Which belief and value should I follow? These questions are among the things that the youth consider. These questions also arise for individuals who are looking for identities. It tells how the phases of a teen's life are very synonymous with the phase of seeking identity. Identity search should be in-depth guidance and assessment not to be affected or affected by various unhealthy elements. ${ }^{32}$ Therefore, the perfection in the tasks to shaping youth physically, psychologically, spiritually and religiously is required to follow the rules and guidelines contained in the Qur'an and the Sunnah. Details that only touch about psychological development alone as find in the western psychology cannot satisfy the spiritual aspect that the youth need. Islam sees the needs of youth in holistic psychological and spiritual aspects in every process of development. $^{33}$

Islam perceives people at youth phase, naturally having gained awareness about themselves, to embrace religious trust (taklif) and social life. Al-Ghazālī named this phase at the level of 'aqil, where the level of intellectual development was at the height of the culmination so that the children were able to distinguish

29 Jas laile Suzana Jaafar, Pengenalan kepada Psikologi kanak-kanak dan Remaja, (Selangor: Arah Pendidikan Sdn. Bhd., 2008); Rolf E. Muuss, Theories of Adolescence, ed 2 (New York:Random House, 1969), 6.

30 Anuar Puteh, "Perkembangan dan Pembentukan Remaja" 82.

31 Abdul Mujib dan Jusuf Mudzakir, Nuansa-Nuansa Psikologi Islam (Jakarta: PT Raja Grafindo Persada, 2001). 56.

32 Azizi bin Yahya \& Jaafar Sidek, Membentuk Identiti Remaja (Pahang: PTS Professional, 2005).1.

33 Che Zarrina Saari \& Joni Tamkin Borhan, "Psikospiritual dan Metodologi Pengaplikasiannya dalam Kehidupan" in Koleksi Kertas Kerja Isu Semasa: Menghurai Permasalahan Islam Semasa (Kuala Lumpur: Jabatan Kemajuan Islam Malaysia, 2006), 67. 
right and wrong actions. ${ }^{34}$ The state of mind becomes one of the obligatory conditions for a person to accept the burden and responsibility of religion, and likewise the crazy person is out of the responsibility. Furthermore, every practice of deeds for men and women of Islam at this stage begins to be considered and will be rewarded with reward or punishment. ${ }^{35}$

All the actions done by them, implying whether it is good or bad, will receive a fair reward in the hereafter because of what has been done. ${ }^{36}$ Youth also need to preserve themselves from all acts of immorality and fill themselves with good deeds because the stage of youth is a time where the impulse of desire begins to grow rapidly.

A youth who gives a positive assessment of self-esteem can behave as accepted in the norms of society and in accordance to religious teachings. An individual who has high self-esteem is also said to be able to act as a responsible member of the community and thus able to develop the community and the nation. Hence, through the conception of self-esteem build in Islamic psychospiritual discipline that have a combination of revelation of God sources and empirical of human beings' efforts, the benefits can be seen not only in temporal aspect of one's life but also in eternal life as Islam emphasizes the ultimate goal of life are success and happiness in the hereafter.

In order to develop noble morals among youth, it requires them to work hard. Similar conditions need to be done to grow high self-esteem. According to al-Mawardi, there are two main factors that can lead to the construction of high self-esteem, firstly, high determination ('uluw al-himmah) and strong motivation (aldawafi ); and secondly, noble virtues or noble souls (sharaf al-

34 Wilcox, Lynn, Sufism and Psychology: Ilmu Jiwa Berjumpa Tasawuf: Sebuah Upaya Spiritualisasi Psikologi, (trans.) IG Harimurti Bagoesoka (Jakarta: PT Serambi Ilmu Semesta, 2003), 21; Mujib dan Mudzakir, Nuansa-Nuansa Psikologi Islam, 89.

35 Ismail Kamus \& Mohd Azrul Azlen Abd Hamid, Indahnya Hidup Bersyariat: Modul Fardu Ain Diri, Keluarga dan Masyarakat (Kuala Lumpur: Telaga Biru, 2013).44.

36 Wan Sallha Yusoff et al., "Faktor-faktor yang Mempengaruhi Penentuan Identiti Diri Remaja Melayu" (Paper presented in Seminar Pendidikan Melayu Antarabangsa 2010, organised by Unit Kajian Strategik, Universiti Malaysia Perlis, 29-31 Mac 2010), 1.

37 Mujib dan Mudzakir, Nuansa-Nuansa Psikologi Islam. 89. 
nafs).$^{38}$ The first factor signifies the power of self-indulgence that inspires the living being, which then results in behavior that drives and directs to a particular goal or purpose. With a high determination and a strong motivation, the attitude of responsibility will be born in youth to meet the demands of achieving and maintaining the goals to attained in life. ${ }^{39}$ Hence, youth will also concentrate on something more important where this can prevent a person from being ignorant that leads to disdain, thereby lowering one's self-esteem.

The second factor that contributes to the development of selfesteem is to have a noble soul. To have a noble soul, the youth must have noble characters. This morality, according to Ibn Miskawayh and al-Ghazali, is a characteristic embedded in the soul that produces various acts easily without requiring a person to think or make judgment. ${ }^{40}$ In contrast to high determination and strong motivation, the noble soul requires youth to undergo the process of forming, nurturing (ta'dib) and training (tarbiyah) by always practicing the noble characters and disciplined. ${ }^{41}$ The standard for this nobility is the personality of the Prophet as mentioned in the verse above.

The process of cultivating high self-esteem in shaping youth personality supposed to be done by youth with the teaching, instruction and supervision by parents or teachers or murshid (spiritual guide) encompasses two major elements as mentioned above, high determination and strong motivation; as well as a noble soul. The first stage in the formation of youth self-esteem in shaping their personality is to cultivate high determination and strong desire in themselves to obtain moral perfection because the process requires struggling and persistence. ${ }^{42}$ At this stage, the first step that needs to be done is to educate youth concerning the

38 Al-Māwardī, Ādāb al-Dunyā wa al-Dīn, 321.

39 Muhammad 'Uthmān Najātī, al-Qur'ān wa 'Ilm al-Nafs (Cairo: Dār alShurūq, 2005), 27; Muhammad 'Utsman Najati, Jiwa Manusia dalam Sorotan Al-Quran: Al-Quran wa Ilmu an-Nafs (trans.) Ibn Ibrahim, (ed.) Ali Yahya (Jakarta: Cendekia Sentra Muslim, 2001), 23.

40 Ibn Miskawayh, Tahdhīb al-Akhlaq wa Tathir al-A'raq (Cairo: al-Matba'ah al-Mișriyyah, 1934), 40; al-Ghazālī, Ihyā 'Ulūm al-Dīn, 3:6.

41 Al-Māwardī, Ādāb al-Dunyā wa al-Dīn, 250.

42 H. Abuddin Nata, Akhlak Tasawuf dan Karakter Mulia (Jakarta: Rajawali Press, 2014), 6. 
importance of a human being to strive to improve behavior and achieve moral perfection. Exposure to the true concept of selfesteem is also important. The self-esteem that we want to achieve is not just to get the recognition of the surrounding society and self-satisfaction, but the recognition and reassurance of Allah is the real goal of self-esteem organized in Islam. ${ }^{43}$

The next process to be done by youth with the teaching, instruction and supervision by parents or teachers or murshid (spiritual guide)is to form a noble soul by self-practicing noble qualities. At this stage, youth will be exposed and explained to the three states of the human psyche that are nafs al-ammarah, nafs al-lawwamah and nafs al-mutma'innah which affected the way of human behavior. The youth are encouraged to strive to free themselves from the lowest level soul, nafs al-ammarah which is the instinct of evil as well as the middle level of soul, nafs allawwamah which is regarded as indeterminate souls that tend to choose either kindness or evil. They are inspired to reach the highest and noble rank of soul, nafs al-mutma'innah. ${ }^{44}$ In order to achieve this process, youth need to perform tazkiyah al-nafs which is the process of self-purification and self-cleansing that includes the cleansing of soul from reprehensible and bad behavior and decorate it with commendable and good morals. ${ }^{45}$

Further in the next process, youth has to focus on iffah (preservation of purity) with the teaching, instruction and also supervision by parents or teachers or murshid (spiritual guide). 'Iffah is a state where lusts (shahawat) are easily commanded by the power of mind ( aqal) so that their feelings and emotions are in their mind ('aqal) control. ${ }^{46}$ In this context, 'iffah indicates the process of learning on how the youth must guard their genitals from what is banned and to keep good speech and not to speak lies. Al-Ghazali further explains that the abdomen, genitalia and mouth are the birthplace of lusts, in which soul training (riyadah al-nafs) are required to regulate the organs. ${ }^{47}$ If these three

43 Mohd Nasir Omar, Akhlak dan Kaunseling Islam, 106.

44 Al-Ghazālī, Ihyā' ' 'Ulum al-Dīn, 3:5.

45 Al-Ghazālī, Ihyā' 'Ulum al-Dīn, 8:13; Sa'īd Hawwa, al-Mustakhlaṣ fì

Tazkiyah al-Nufus (Beirut: Dār 'Ammar, n.d.), 10.

46 Al-Māwardī, Ādāb al-Dunyā wa al-Dīn, 324.

47 Al-Ghazāīi, Ihya' 'Ulum al-Dīn, 3:73. 
members are in good condition and prosperous, then a one's self will be preserved.

Then in the next process, youth with the teaching, instruction and supervision by parents or teachers or murshid (spiritual guide) need to practice nazahah (self-purification). It is a process involving the practice of cleansing and purifying the hearts from the greed of the world and purifying the heart from doubt and suspicion. The worldly love only leads to disadvantages and causes the youth to neglect and turn away from focusing on the issues and practices for the life in the hereafter. ${ }^{48}$ Youth who wants to have a high self-esteem needs to remove the greed in themselves. The greediness causes people to feel incapable of releasing their belongings no matter how desperate the situation is, even though the matter is considered as despicable. ${ }^{49}$ By having piety in the heart, youth can control themselves from being mastered by greed and love of the world. Hence, it is encouraging to educate youth to spend their wealth by giving alms to the needy which can instill generosity in their heart.

The process of nazahah also includes purification of the heart from doubt because it will bring error when it comes to choosing the truth and reject the falsehood. ${ }^{50}$ The same situation for a oneself who does not have a stand and valued something for selfinterest and has other intentions are on the contrary. In the context of youth today, the cultivation of self-determination requires parents and teachers' guidance and educating. This process is very important in guiding the youth to be unaffected by peers or unhealthy environment that can form low self-esteem in themselves.

The last process in the development of youth self-esteem is siyanah. Youth with the teaching, instruction and supervision by parents or teachers or murshid (spiritual guide) involves in the training of self-preservation and protection. ${ }^{51}$ The first aspect of self-preservation in achieving high self-esteem is to search for

48 Wan Mohd. Shaghir Abdullah, Hidayatus Salikin Syeikh Abdus Shamad alFalimbani (Kuala Lumpur: al-Hidayah Publisher, 1997), 44.

49 Al-Māwardī, Ādāb al-Dunyā wa al-Dīn, 330.

50 Al-Māwardī, Ādāb al-Dunyā wa al-Dīn, 330; Al-Tuwij̄̄īī, Mawsū'at Fiqh alQulūb fì Daw' al-Qur'ān wa al-Sunnah, 3:586.

51 Al-Māwardī, Ādāb al-Dunyā wa al-Dīn, 332. 
property only to fulfil the needs of life and to keep ourselves from receiving the burden of giving and always asking for help. ${ }^{52}$ The second aspect of self-preservation is to be careful of gifts received and the love to ask others for help. When a person receives gifts from others, his liberty will be limited, causing him to be dominated by the people who gives and put others burden on him. Humans who often burden other people will be despicable and causes their self-esteem to be low in the presence of those who help him.

All these elements appeared in the concept of self-esteem from Islamic psycho-spiritual study needs to be applied and nurtured as early as adolescent age. These processes as a whole require the involvement of at least two parties ie adolescents and parents Encouraging youth to be self-reliant is the first step before they actually enter the next real-world family and job life of a more challenging home.

\section{Conclusion}

From the overall discussion, it can be concluded that muru'ah or self-esteem is one of the vital aspects that plays an important role in building human personality, especially in the quest for the identity of the present-day youth who are constantly exposed to the various negative elements and the growing influence of peers. The self-esteem concept has long been discussed in psychology, focusing only on empirical method based on merely human judgment without associating it with a spiritual demand that emphasizes the relationship with the Creator. Islam as a way of life, has provided the basis of self-esteem. The self-esteem concept that should be pursued by youth in shaping personality must embrace the spiritual aspects together with the physical aspects. A youth who has trained in achieving self-esteem does not merely develop a high self-esteem, but the construction of it directly builds good personal characters and noble personalities.

52 Muhammad ibn Muhammad al-Ghazālī, Mīzan al-Amal (Cairo: Dār al-Che Zarrina Saari \& Joni Tamkin Borhan. "Psikospiritual dan Metodologi Pengaplikasiannya dalam Kehidupan" in Koleksi Kertas Kerja Isu Semasa: Menghurai Permasalahan Islam Semasa. Kuala Lumpur: Jabatan Kemajuan Islam Malaysia, 2006.Ma'ārīf, 1964), 376. 
Youth who have good characters and noble personalities will put Allah the Almighty's assessment as the main point before considering other judgments.

\section{Acknowledgement}

Researcher would like to thank the University of Malaya for granting 9 months sabbatical leave from September 2017 to May 2018. This paper is resulted from research done during the sabbatical leave.

\section{References}

Abdul Mujib dan Jusuf Mudzakir. Nuansa-Nuansa Psikologi Islam. Jakarta: PT Raja Grafindo Persada, 2001.

Al-Basrī, Abī Hasan 'Alī bin Muḥammad Habīb. Ādāb al-Dunya wa al-Din. T.tp: Societi Algerolibanaise, 2006.

Al-Ghazālī, Muḥammad ibn Muḥammad al-Ghazālī. Ihyyà' 'Ulūm al-Dīn. Beirut: Dār al-Kutub al-'Ilmiyyah, 2001.

Al-Ghazālī, Muḥammad ibn Muḥammad al-Ghazālī. Mīzan alAmal. Cairo: Dār al-Ma‘ārīf, 1964.

Al-Ghazālī, Muḥammad ibn Muḥammad. Ihyyā' 'Ulūm al-Dìn. Beirut: Dār al-Kutub al-'Ilmiyyah, 2001.

Al-Jawziyyah, Ibn Qayyim. Madārij al-Sālikīn: Bayn Manāzil Iyyāka Na'bud wa Iyyāka Nasta' ī. (Beirut: Dār al-Kutub al'Ilmiyyah, t.t.

Al-Māward̄̄, Ali Ibn Muhammad Ibn Habib. Ādāb al-Dunyā wa al-Dīn. T.tp: Jāmi‘ al-Huqūq Mahfūzạah, 2007.

Al-Mu'jam al- 'Arabī al-Asāsī. Alecso: n.p,1989).

Al-Tuwijīīī, Muḥammad Ibrāhīm 'Abd Allāh. Mawsū'at Fiqh alQulūb fì Daw' al-Qur'ān wa al-Sunnah. Baridah: Dār Asdad alMujtami', 2012.

Azizi bin Yahya \& Jaafar Sidek. Membentuk Identiti Remaja (Pahang: PTS Professional, 2005.

Azizi Yahaya \& Halimah Ma'alip. Estim Kendiri Remaja. Skudai, Johor: Universiti Teknologi Malaysia, 2010.

Coopersmith, Stanley. The Antecedents of Self-esteem. San Francisco: W. H. Freeman and Company, 1967.

Dutton, Keith A. \& Brown, Jonathon D. "Global Self-Esteem and Specific Self-Views as Determinants of People's Reactions to 
Success and Failure" Journal of Personality and Social Psychology, 73 (1997): 139.

Francis R. Kick, Jr. "The Self Perceptions of Self-Concept and Self-Esteem: A Theoretical Analysis." Master Thesis, Antioch University, 1992.

Frey, D. \& Carlock, C. J., Enhancing Self-Esteem. United States of America: Accelerated Development, Inc, 1987.

Gecas, Viktor. "The Self-Concept", Annual Review of Sociology, 8 (1982.

H. Abuddin Nata. Akhlak Tasawuf dan Karakter Mulia. Jakarta: Rajawali Press, 2014.

Hawwa Sa‘īd. al-Mustakhlas fì Tazkiyah al-Nufus. Beirut: Dār 'Ammar, n.d.

Heatherton, Todd F., Carrie L. Wyland, \& S. J. Lopez. "Assessing self-esteem," Positive Psychological Assessment: A Handbook of Models and Measures (2003), 220.

Ibn Miskawayh. Tahdhīb al-Akhlaq wa Tathir al-A 'raq. Cairo: alMatba'ah al-Mișriyyah, 1934.

Ismail Kamus \& Mohd Azrul Azlen Abd Hamid. Indahnya Hidup Bersyariat: Modul Fardu Ain Diri, Keluarga dan Masyarakat. Kuala Lumpur: Telaga Biru, 2013.

Jas laile Suzana Jaafar. Pengenalan kepada Psikologi kanak-kanak dan Remaja. Selangor: Arah Pendidikan Sdn. Bhd., 2008.

Johnson, Briam W., et al. "The Coopersmith Self-Esteem Inventory: A Construct Validation Study," Educational and Psychological Measurement, 43 (1983).

Kamus Besar Arab-Melayu Dewan. Kuala Lumpur: Dewan Bahasa dan Pustaka, 2006), 2184, entri "Muruah", 2184.

M. Amin Abdullah, "Etika Tauhidik Sebagai Dasar Kesatuan Epistemologi Keilmuan Umum dan Agama," dalam Integrasi Sains-Islam: Mempertemukan Epistemologi Islam dan Sains. Yogyakarta: Pilar Religia, 2004.

M.Amin Abdullah et al., Integrasi Sains-Islam: Mempertemukan Epistemologi Islam dan Sains. Yogyakarta: Pilar Religia, 2004.

Mohd Nasir Omar. Akhlak dan Kaunseling Islam. Kuala Lumpur, Utusan Publications and Distributors Sdn Bhd, 2005.

Muhammad 'Utsman Najati, Jiwa Manusia dalam Sorotan AlQuran: Al-Quran wa Ilmu an-Nafs (trans.) Ibn Ibrahim, (ed.) Ali Yahya. Jakarta: Cendekia Sentra Muslim, 2001. 
Najātī. Muḥammad 'Uthmān. Al-Qur'ān wa 'Ilm al-Nafs. Cairo: Dār al-Shurūq, 2005.

Nor Azah Abdul Aziz \& Che Zarrina Saari. "Menangani Permasalahan Laman Web Pornografi: Antara Perisian Penapis, Penguatkuasaan Undang-Undang dan Amalan Spiritual," Journal of Islamic and Arabic Education 3, no. 1 (2011), 29-46.

Rohana Binti Zakaria, Zikmal Fuad \& Mohd Nur Adzam Rasdi. "Implikasi Tadabbur Al-Quran dalam Pembentukan Insan Yang Berkualiti di Sudut Akhlak," (Paper presented in International Conference on Postgraduate Research 2014 (ICPR 2014), Kuala Lumpur, 1-2 December 2014), 266.

Rolf E. Muuss, Theories of Adolescence, ed 2. New York: Random House, 1969.

Sharifah Basirah Syed Muhsin \& Che Zarrina Sa'ari. Kaedah Prikoterapi Islam Berasaskan Konsep Maqamat Abu Talib AlMakki. Kuala Lumpur: Dewan Bahasa dan Pustaka, 2015.

Wan Mohd. Shaghir Abdullah, Hidayatus Salikin Syeikh Abdus Shamad al-Falimbani. Kuala Lumpur: al-Hidayah Publisher, 1997.

Wan Sallha Yusoff et al., "Faktor-faktor yang Mempengaruhi Penentuan Identiti Diri Remaja Melayu" (Paper presented in Seminar Pendidikan Melayu Antarabangsa 2010, organised by Unit Kajian Strategik, Universiti Malaysia Perlis, 29-31 Mac 2010), 1.

Wilcox, Lynn, Sufism and Psychology: Ilmu Jiwa Berjumpa Tasawuf: Sebuah Upaya Spiritualisasi Psikologi, (trans.) IG Harimurti Bagoesoka. Jakarta: PT Serambi Ilmu Semesta, 2003. Wilis Srisayekti David A. Setiady \& Rasyid Bo Sanitioso. "Hargadiri (Self-esteem) Terancam dan Perilaku Menghindar", Jurnal Psikologi 42 (2), (2015) 146. 